\title{
Térdporc szegmentálása MR-felvételekből mesterséges intelligencia segítségével
}

\author{
Szoldán Péter ${ }^{1}$ - Egyed Zsófia dr. ${ }^{2}$ - Szabó Endre dr. ${ }^{3}$. Somogyi János ${ }^{1}$ \\ Hangody György dr. ${ }^{2}$ - Hangody László dr. ${ }^{2,4}$ \\ ${ }^{1}$ MedInnoScan Kutatás-fejlesztési Kft., Budapest \\ ${ }^{2}$ Uzsoki Utcai Kórház, Budapest \\ ${ }^{3}$ Rényi Alfréd Matematikai Kutatóintézet, Budapest \\ ${ }^{4}$ Semmelweis Egyetem, Általános Orvostudomány Kar, Traumatológiai Tanszék, Budapest
}

\begin{abstract}
Bevezetés: A térdízületnek ultrafriss osteochondralis allograft segítségével történő részleges ortopédiai rekonstrukciója képalkotó vizsgálatokon alapuló pontos tervezést igényel, mely folyamatban a morfológia felismerésére képes mesterséges intelligencia nagy segítséget jelenthet.

Célkitüzés: Jelen kutatásunk célja a porc morfológiájának MR-felvételen történő felismerésére alkalmas mesterséges intelligencia kifejlesztése volt.

Módszer: A feladatra legalkalmasabb MR-szekvencia meghatározása és 180 térd-MR-felvétel elkészítése után a mesterséges intelligencia tanításához manuálisan és félautomata szegmentálási módszerrel bejelölt porckontúrokkal tréninghalmazt hoztunk létre. A mély convolutiós neuralis hálózaton alapuló mesterséges intelligenciát ezekkel az adatokkal tanítottuk be.

Eredmények: Munkánk eredménye, hogy a mesterséges intelligencia képes a meghatározott szekvenciájú MR-felvételen a porcnak a mútéti tervezéshez szükséges pontosságú bejelölésére, mely az első lépés a gép által végzett mútéti tervezés felé.

Következtetés: A választott technológia - a mesterséges intelligencia - alkalmasnak tứnik a porc geometriájával kapcsolatos feladatok megoldására, ami széles körü alkalmazási lehetőséget teremt az ízületi terápiában.

Orv Hetil. 2021; 162(9): 352-360.
\end{abstract}

Kulcsszavak: térd, porc, allograft, mélytanulás

\section{Segmentation of knee cartilages in MR images with artificial intelligence}

Introduction: The partial orthopedic reconstruction of the knee joint with an osteochondral allograft requires precise planning based on medical imaging reliant; an artificial intelligence capable of determining the morphology of the cartilage tissue can be of great help in such a planning.

Objective: We aimed to develop and train an artificial intelligence capable of determining the cartilage morphology in a knee joint based on an MR image.

Method: After having determined the most appropriate MR sequence to use for this project and having acquired 180 knee MR images, we created the training set for the artificial intelligence by manually and semi-automatically segmenting the contours of the cartilage in the images. We then trained the neural network with this dataset.

Results: As a result of our work, the artificial intelligence is capable to determine the morphology of the cartilage tissue in the MR image to a level of accuracy that is sufficient for surgery planning, therefore we have made the first step towards machine-planned surgeries.

Conclusion: The selected technology - artificial intelligence - seems capable of solving tasks related to cartilage geometry, creating a wide range of application opportunities in joint therapy.

Keywords: knee, cartilage, allografts, deep learning

Szoldán P, Egyed Zs, Szabó E, Somogyi J, Hangody Gy, Hangody L. [Segmentation of knee cartilages in MR images with artificial intelligence]. Orv Hetil. 2021; 162(9): 352-360.

(Beérkezett: 2020. augusztus 10.; elfogadva: 2020. szeptember 22.) 


\section{Rövidítések}

CAD $=$ (computer-assisted diagnostics $)$ komputerasszisztált diagnosztika; $\mathrm{CT}=$ (computed tomography) számítógépes tomográfia; $\mathrm{DCNN}=$ (deep convolutional neural networks $)$ a convolutiós múvelet több rétegben megismételt alkalmazásán alapuló neuralis hálózat; DSC = (Dice similarity coefficient $)$ Dice hasonlósági együttható (speciális, két halmaz hasonlóságának összehasonlítására használt matematikai érték); FN = (false negative) tévesen negatívnak ítélt, fals negatív érték; FP = (false positive) tévesen pozitívnak ítélt, fals pozitív érték; MR = (magnetic resonance $)$ mágneses magrezonancia $; \mathrm{OAI}=($ Osteoarthritis Initiative) az amerikai egészségügyi kormányzat multicentrikus longitudinális prospektív obszervációs kutatása az osteoarthritis kialakulásának és progressziójának követésére és meghatározó biomarkerek kutatására; $\mathrm{TN}=$ (true negative) helyesen meghatározott, valódi negatív érték; TNR = (true negative rate) specificitás; $\mathrm{TP}=($ true positive $)$ helyesen meghatározott, valódi pozitív érték; TPR = (true positive rate $)$ szenzitivitás

\section{Ultrafriss osteochondralis allograft unikompartmentális károsodás terápiájára}

Az ízületi csúszófelszínek kopását, traumás károsodását a morbiditási adatok szerint a populációt érintő egyik leggyakoribb betegség típusaként tartjuk nyilván. A fájdalmat, mozgáskorlátozottságot okozó, a fizikai teljesítőképességet csökkentő ízfelszín-destrukciók sebészi kezelésére alapvetően kétféle megoldás áll rendelkezésünkre. Az egyik törekvés során a különböző porcfelszínképző technikák alkalmazásával a destruált porcfelszínt, illetve az alapját képező csontalapot alapvetően biológiai módszerrel próbáljuk helyreállítani. Ilyen technikák a természetes regenerációt elő́mozdító eljárások: biodegradábilis vázszerkezetek beültetése, sejtkultúrákkal történő felszínképzések, valamint autológ és allogén porc-csont átültetések [1]. Ezek segítségével az eredetivel azonos vagy azt megközelítő minőségú saját csúszófelszín hozható létre, de mindezen technikák közös jellemzője, hogy csak fokális károsodások kezelésére alkalmasak. Méretkorlátaikat illetően a kis kiterjedésú és felszínes laesiók kezelése lehetséges ilyen módon, valamint a defektuson kívüli ízületi csúszófelszínek jó minősége is követelmény.

Amikor a felszínkárosodás kiterjedt, az ízületi felszínek nagy része súlyosan kopott, endoprotetikai lehetőségek jelenthetnek megoldást. A jelenleg használatos fém-, múanyag, illetve kerámiaanyagú endoprotézisek beültetésével viszonylag gyors rehabilitáció után a fájdalom megszűnése, jó funkció és terhelhetőség biztosítható, de az így beültetett implantátumok évtizedek alatt meglazulhatnak, újabb nagy megterhelést jelentô mútéti igényt támasztva. Az endoprotetikai beavatkozások ritka, de súlyos korai, illetve az előbbiekben említett késői szövődményei miatt a mozgásszervi sebészet egyik fó törekvése az, hogy minél hosszabb ideig és minél kiterjedtebben használjunk biológiai felszínképző lehetőségeket.

Az előbbiekben említett két fó sebészeti kezelési csoport indikációs lehetőségei között jelenleg elég széles, megoldatlan köztes terület húzódik. A térdízület vonat- kozásában például a betegek jelentős csoportja olyan kiterjedt unikompartmentális károsodással rendelkezik, amely már nem teszi lehetővé az említett biológiai felszínképző módszerek alkalmazását, de a beteg életkora, az elváltozás súlyossága és számos egyéb szempont miatt az endoprotetikai megoldás az említett hosszú távú szövődmények lehetősége miatt korainak minősül. Ezekre az esetekre jelenleg csak kompromisszumos megoldásokkal rendelkezünk.

A kiterjedt, illetve mély fokális defektusok biológiai kezelésére, a károsodás területén üvegporc minőségú felszín kialakítására az eddigi irodalmi tapasztalatok alapján a homológ porc-csont szöveti transzplantáció, osteochondralis allograft beültetése ad lehetőséget. Az eddigi, zömmel észak-amerikai gyakorlat szövetbanki úton biztosított, 10 napos és 3 hetes kor közötti kivételből származó osteochondralis allograft blokkokat használ [2]. Bár a masszív osteochondralis defektusok kezelésében az említett eljárás kizárólagos biológiai megoldásnak számít, a megfigyelések azt mutatják, hogy az ilyen módon átültetett osteochondralis allograftok hialinporcsejtjei a donáció és a beültetés közt eltelt idő hosszúsága miatt optimális esetben is csak $50 \%$-os túlélést mutatnak [3]. Ez hosszú távon az újonnan kialakított felszín ismételt degenerációjához vezet.

Alapkutatásos eredmények azt mutatták, hogy a kivétel és a beültetés között eltelt idő csökkentésével a sejttúlélés javítható. Mindezek alapján 10 évvel ezelött vezettük be az Uzsoki Utcai Kórház Ortopéd-Traumatológiai Osztályán az úgynevezett ultrafriss osteochondralis allograftok beültetésének mútéti technikáját [4]. A kialakított gyakorlat szerint a masszív osteochondralis defektus miatt mútétre váró betegeket várólistára helyezzük, és donáció esetén sürgősségi behívás útján kerülhetnek a szövetkivételtől számított 24-36 órán belül mútétre. Az elmúlt 10 év gyakorlata, klinikai és radiológiai eredményei, a kontroll artroszkópos vizsgálatok és a biopsziák szövettani elemzése kiváló funkcionális eredményeket és közel 100\%-os sejttúlélést mutatott. A jó eredmények ismeretében a technikát a térdízületen kívül a boka- és a csuklóizület kiterjedt és bipoláris károsodásainak kezelésére is elkezdtük használni.

A mútét komoly szervezési, instrumentális és sebészeti felkészültséget igényel, és a legfő́bb technikai követelmény a bonyolult domborulatú ízfelszínek egymással tökéletesen illeszkedő kongruens kialakítása. A jelenlegi gyakorlat során a donor-recipiens párosítás, illetve a mútét során a defektus- és oltvány-előkészítés és -illesztés egyaránt az operáló sebész vizuális és szakmai megítélése alapján történik. Amennyiben az elpusztult csúszófelszín helyén kialakítandó felszín és az alatta lévő csonthiány geometriája és mérete pontosabban illeszthetô lenne a donor paramétereivel, az komoly technikai támogatást jelentene a mútét elvégzésében. Figyelembe véve az eddigi 10 éves gyakorlat során nyert jó grafttúlélési tapasztalatokat, a mútétnek az előbbiekben említett technikai támogatásával az indikáció a jelenlegi, viszonylag ritka masszív 
osteochondralis laesiókon túl kiterjeszthető lenne a gyakori unikompartmentális problémákra. A károsodott ízületek defektusait és porcminőségét jól leképező MR-adatok összevetése a donor paramétereivel lehetőséget nyújt nemcsak a gyors és optimális donor-recipiens párosításra, hanem arra is, hogy a donor mindkét térdízületének felhasználásával egy donációból több mütét elvégzésére alkalmas számos blokk kinyerhetô legyen.

\section{Mesterséges intelligencia a képalkotó vizsgálatokon alapuló diagnosztika szolgálatában}

A képalkotó felvételek elkészítésének digitalizálása jelentős diagnosztikai fejlődést indított el. A leképezés elve változatlan ugyan, mégis alapjaiban új, komplex módszerek alkalmazásával részletgazdagabb kép, pontosabb eredmény nyerhetô ki a vizsgálatokból. Ezen túlmenően a különböző 'pre- és postprocessing' technikák az ionizáló sugárzást használó vizsgálatok esetén jelentôs dózismegtakarítást is lehetővé tettek. A digitális képfeldolgozás a jel/zaj arány növelésével, egyes részek kontrasztkiemelésével, a minimális és maximális dóziselnyelés megjelenítésével, 3D rekonstrukcióval, valamint különböző metszeti síkok együttes ábrázolásával tökéletesíti a képet és segíti a radiológus munkáját.

Ezzel párhuzamosan az informatika fejlődése először a komputerasszisztált diagnosztika (CAD) módszerét hozta létre, mely különböző algoritmusok segítségével ad diagnosztikai javaslatokat, illetve jelöl ki releváns részeket a humán diagnoszta számára a felvételeken.

További komplex módszer a radiomika, mely a felvétel olyan kvantitatív jellemzőinek kiszámolását célozza, amelyek diagnosztikai értékkel bírnak [5].

A mesterséges intelligencia, azon belül a mélytanulás alkalmazása ennél is többre képes. A képalkotó vizsgálat eredményeképpen létrejövő felvételen a releváns területeket bejelölve és ily módon tréninghalmazt, más néven tanitóhalmazt létrehozva, a neuralis hálózat a tréninghalmaz elemeit olyan módon elemzi, dolgozza fel, hogy potenciálisan eddig ismeretlen, az emberi szem, illetve a szakmai tudás számára új összefüggéseket is találhat, növelheti a diagnosztika pontosságát, illetve átvállalhat bizonyos feladatokat a humán diagnosztától. Ez a módszer, a tanítási folyamat a radiológusok és informatikusok szoros együttmúködését igényli.

\section{A képalkotó vizsgálatok anyagának szemantikus szegmentálása}

Képalkotó vizsgálatok anyagából (a leginkább CT-ről és MR-ről van szó) kiemelni és egyértelmúen bejelölni a jelentőséggel bíró objektumokat orvosi vagy legalább orvosi felügyeletet, ellenőrzést igénylő feladat.
Ezen követelmények már több mint egy évtizede foglalkoztatják az orvosi, radiológusi szakmát a mesterséges intelligencián kívül is [6]. Szakmai jelentősége lehet bármely anatómiai képlet, illetve patológiai elváltozás kijelölésének, szegmentálásának. Például tüdődaganatok esetén az onkológus nemcsak a tüdőrákszűréshez szükséges diagnosztikai célból [7], hanem sugárterápiás tervezésnél is használja a szegmentálást [8].

A térdízület diagnosztikájában is jelentős szerepet játszik az anatómia modellezése, melyre szintén lehet szegmentálást alkalmazni. Több mint egy évtizede múködik az OAI (Osteoarthritis Initiative), az amerikai egészségügyi kormányzat által támogatott kezdeményezés, mely multicentrikus longitudinális prospektív obszervációs kutatás az osteoarthritis kialakulásának és progressziójának követésére és meghatározó biomarkerek kutatására [9]. Az így keletkezett nagy képi adatbázisa szegmentálási workshop alapját képezte 2010-ben Kínában, Pekingben [10]. Az OAI azóta is elérhető az egyre bővülő anyagával, és különböző félautomata szegmentálási módszerek próbálhatók ki rajta.

\section{A mesterséges intelligencia tanitása}

A mesterséges intelligencia (neuralis hálózat) tanítása úgy zajlik, hogy a számítógép MR-felvételeket kap, és megpróbálja azokat a legjobb tudása szerint automatikusan szegmentálni. Ezután megkapja a releváns manuális szegmentálásokat is, és azok segítségével kiértékeli saját szegmentálását. Az értékelés alapján úgy változtatja, módosítja a saját belső paramétereit, hogy javuljon a szegmentálás minősége, azaz jobban hasonlítson a kézi szegmentáláshoz. Ezt az eljárást kell ciklikusan ismételni mindaddig, amíg a szegmentálás minősége eléri a kívánt mértéket.

A tapasztalat azt mutatja, hogy nagyon hasonló típusú neuralis hálózatok nagyon sokféle szegmentálási feladatot képesek végrehajtani; nem a hálózat struktúrája, hanem a paraméterek döntik el, hogy végül milyen objektumokat fog a hálózat felismerni, szegmentálni, és hogy mennyire lesz pontos az eredmény.

Fontos, hogy a mesterséges intelligencia ne csak azokat az MR-felvételeket tudja szegmentálni, amelyeken tanult, hanem új felvételeket is, szakkifejezéssel: jól általánosítson. Különösen fontos ez esetünkben, hiszen a manuális szegmentálásokra azok előállításából kifolyólag jellemző az inter- és intraoperátori variabilitás. Egy jól általánosítani tudó mesterséges intelligencia képes felülemelkedni ezen és leszürni a lényeget, ami esetünkben a szegmentálás pontosságának növekedésével kecsegtet. Ezért a mesterséges intelligenciát úgy értékeljük, hogy a tanításból kizárt, úgynevezett teszthalmazban levő MRfelvételeken „vizsgáztatjuk”. 


\section{Módszer}

\section{Neuralis hálózat}

A képszegmentálási feladat végrehajtásához az egyes pixeleket - vagy 3D kép esetén voxeleket - különböző objektumokhoz rendeljük hozzá. A mesterséges intelligencia felől közelítve a szegmentálás tehát osztályozási feladat. Amennyiben csak két ilyen objektumot különböztetünk meg, például porc vagy nem porc, úgy bináris osztályozásnak, vagy más szóval bináris klasszifikációnak hívjuk ezt a fajta szegmentálást.

A képfeldolgozásra használt neuralis hálók általában mély convolutiós neuralis hálók (deep convolutional neural networks, DCNN). A mély convolutiós neuralis hálók a bemeneti képen egymás után több convolutiót alkalmaznak [11]. Bináris klasszifikáció esetén a bemeneti képen elvégzett convolutiók olyan képet eredményeznek, amely mindegyik pixel, illetve voxel előtérhez - esetünkben: térdporchoz - való tartozásának valószínúségét tartalmazza.

Az egyik, kimondottan orvosi képek szegmentálásához fejlesztett convolutiós neuralis háló az úgynevezett U-Net [12]. Ennek az architektúrának a lényege az, hogy először csökkenti a képméretet, ezzel egy időben pedig növeli a képcsatornák számát, majd egy minimális méret elérése után, fordított eljárással, növeli a képméretet és csökkenti a képcsatornák számát. (Az elnevezés, "U-Net” az U betû alakjából mint analógiából származik.) Absztrahálva, az első, csökkentő szakaszban a hálózat a kép fó részeit azonosítja, majd a második, növelő szakaszban a fó részek elhelyezkedését pontosítja.

\section{Architektura}

A U-Net architektúrát Ronneberger és mtsai mutatták be 2015-ben [12]. Eredetileg 2D képekre fejlesztették ki, az architektúra azonban könnyedén általánosítható tetszőleges dimenziójúvá. Mivel esetünkben az MR-felvételek háromdimenziósak, és a keresett objektum, a térdporc is térbeli képződmény, logikus, ha a mesterséges intelligencia is térben végzi a convolutiós és deconvolutiós múveleteket. Bárminemű egyszerüsítés 2D képekre információveszteséggel járna, ami elkerülendő a lehető legpontosabb eredmények érdekében. Az általunk használt architektúrát az 1 ábra mutatja be.

A használt architektúra bemenete tehát esetünkben nem egy $n$-csatornás $2 \mathrm{D}$ kép, hanem egy $n$-csatornás $3 \mathrm{D}$ kép. Az egy convolutióra jutó adatpontmennyiség 2D képek esetén - a gyakran használt $512 \times 512$-es mérettel számolva $-512^{2}=2^{18}$. A 3D kép esetében a számítási kapacitást szem előtt tartva úgy választjuk a képméretet, hogy ez a szám ne nőjön (számottevően). A kiválasztott méret a $64 \times 64 \times 64$, ugyanis $64^{3}=512^{2}=2^{18}$.

Az eredeti U-Net architektúrával megegyezően mi is 5 szint mélységú hálót használunk, azonban a kezdeti 64 csatornát 16-ra csökkentjük, tekintettel a plusz egy dimenzióból származó megnövekedett számítási kapacitásigényre. A legalsó szinten így az eredeti $64 \times 64 \times 64$ méretú képben foglalt információ egy $4 \times 4 \times 4 \times 256$ méretű tenzorba koncentrálódik.

Fontos megemlíteni, hogy a U-Net architektúránk minden szintjén batchnormalizációt használunk, mely fontos szerepet játszik a háló gyors konvergálásában [13].

\section{Térd-MR-felvételek}

Az Uzsoki Utcai Kórház MR-laboratóriumában 2018. 01. 01. és 2020. 05. 31. között 180 térd-MR-vizsgálatot egészítettünk ki a jelen kutatás céljából végzett extrafelvétel-készítéssel. A vizsgálatból kizáró tényező nem volt, bármely, kellően kooperáló páciensen elvégeztük. A tréninghalmazt képező alanyok szelektálása nem volt szükséges, sőt a heterogenitás (bármilyen korú és állapotú beteg) a mesterséges intelligencia tanítása céljából előnyös volt, hogy minél többféle felvétel feldolgozására alkalmas legyen.

A térdízület lágy részeinek pontos ábrázolására olyan standard szekvenciát kerestünk, mely egyrészt vékony szeletes izometrikus 3D ábrázolásra képes, másrészt a különböző szöveteket kellően széles jelintenzitási skálán ábrázolja. Erre nekünk a T2 Trufi 3D szekvencia bizonyult megfelelőnek. A felvételek az Uzsoki Utcai Kórház MAGNETOM Verio típusú, 3T mágneses térerejü MRkészülékén (Siemens, München, Németország) axiális

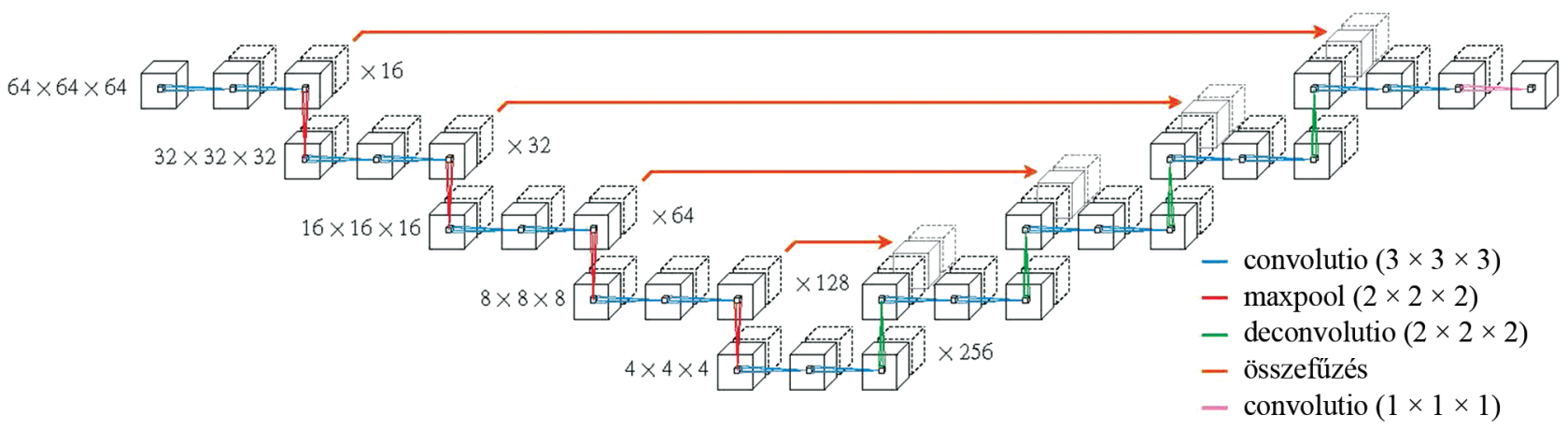

1. ábra

| Az általunk használt neuralis hálózat architektúrája 
síkban, $0,5 \mathrm{~mm} \times 0,5 \mathrm{~mm} \times 0,5 \mathrm{~mm}$ voxel méretben készültek. A 2. és 3. ábrán egy coronalis és egy sagittalis metszetet mutatunk be ugyanarról a térdról, ezekkel a beállításokkal.

További feldolgozás előtt a felvételek anonimizálásra kerültek.

A mesterséges intelligencia tanítása az úgynevezett tréninghalmaz, más néven tanítóhalmaz segítségével történik: példákat mutatunk neki, amelyek alapján megtanulja felismerni, megkülönböztetni azokat a szövettömegeket, kórképeket vagy más paramétereket, amelyeket elvárunk tőle. A tanítás során minél több ilyen mintapéldát tudunk mutatni, annál inkább képes lesz az általános összefüggések felismerésére, „megértésére”.

Ha azt várjuk el a mesterséges intelligenciától, hogy határozza meg az MR-felvételen a térdporcfelületek el-

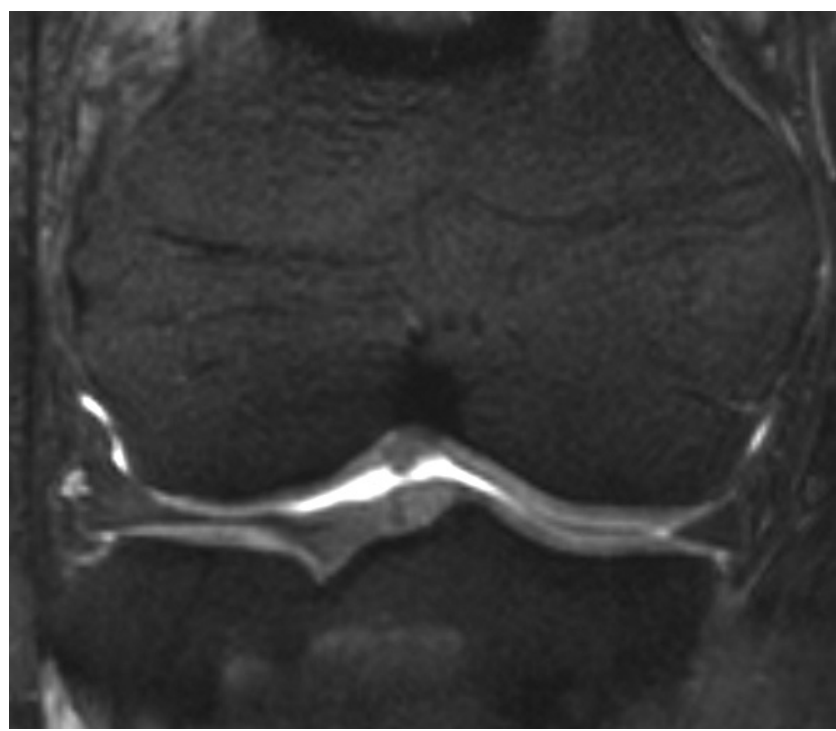

2. ábra $\quad$ A TPR (szenzitivitás) értékeinek eloszlása a teszthalmaz MRfelvételén

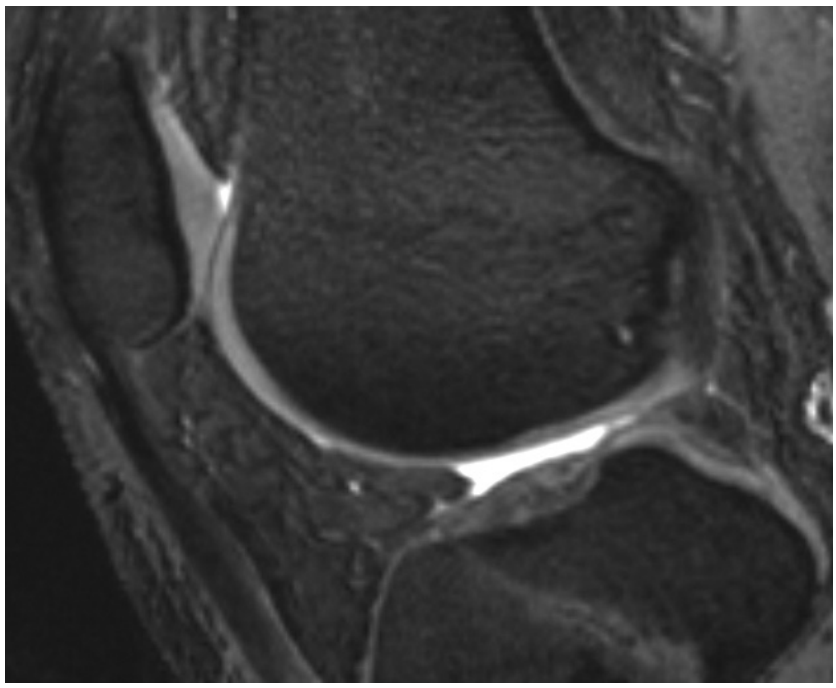

3. ábra

A TNR (specificitás) értékeinek eloszlása a teszthalmaz MR-felvételén helyezkedését, pontos geometriáját, akkor a tréninghalmazt képező felvételeken szükséges neki bejelölni ezeket a szövettömegeket. Ezt a bejelölést hívjuk szemantikus szegmentálásnak, vagy röviden szegmentálásnak.

A szegmentálás helyessége képezi a tréninghalmaz tanítási effektusának alapját, így orvosi szempontból is igen fontos a pontos, konzekvens, egyértelmúen reprodukálható szegmentálás.

A mesterséges intelligencia tanítását előkészítő szegmentálás elsősorban manuálisan végzett munka, melynek keretében az erre szolgáló szoftver segítségével a munkatárs berajzolja a releváns területet. Ezt az „ecset” nevű eszköz segítségével végzi (szabadkézi rajzolás), vagy poligonillesztést, Bézier-görbe-, illetve kvadratikusgörbe-illesztést végez. A manuális munkát megkönnyíthetik bizonyos automatikus vagy félautomatikus módszerek, úgymint 'thresholding', határvonalak detektálása, régiónövelés, kontúrkövetés, alakzatillesztés.

Mind a gépi, mind a manuális módszernek megvannak a maga előnyei és hátrányai is. A gépi félautomata gyors, de önmagában nem elég, hiszen csak egyszerü szabályok szerint tud jelölni, szemantikusan nem; a manuális viszont költséges és lassú, valamint személyfüggő: az interés intraoperátori variabilitás miatt nem reprodukálható tökéletesen. A manuális szegmentálás további nehézsége, hogy a mesterségesintelligencia-rendszer pixel/voxel méretben értékeli a bejelölt adatokat, ami az ember számára a számítógép képernyőjén eredendően értelmezhetetlenül kis méretben jelenik meg. Ezen lehet segíteni nagyítással („zoom” funkció), de az emberi megítélés bizonyos nagyításon felül szintén nehezen értelmez. Az emberi szem számára egy túlságosan felnagyított kontúr inhomogén, szabálytalan elrendezésű, szürke sávként ábrázolódik, melyen pixelnyi pontossággal meghatározni a kontúrt igen nehéz, nem egyértelmű. Így külön feladat volt az optimális nagyítási tartomány meghatározása is.

További nehézséget jelentett, hogy míg a porcszövet teherviselő felületei általában tisztán ábrázolódnak az MR-felvételen, az oldalsó, a condylust körbevevő vékonyabb porcszövetek pontos meghatározása gyakran még a radiológus számára is gondot jelent. Ugyanakkor mivel ezek a porcszövetrészek sem donor-, sem recipiensterületként nem relevánsak, létrehozunk egy külön szegmentálási osztályt ezeknek a nehezen felismerhető területeknek a jelölésére, melyeket ennek segítségével egyes kísérleteknél a mesterséges intelligencia tanításából kizártunk.

A szegmentálási munkát a MedInnoScan Kutatás-fejlesztési Kft. által fejlesztett és a kutatás számára térítésmentesen rendelkezésre bocsátott szegmentálószoftver segítségével végeztük.

\section{Tréning-és teszthalmaz}

A fentebb már említett módszerekkel az MR-felvételek kétféle méretben készültek: $160 \times 320 \times 320$, valamint $144 \times 320 \times 320$. Az inferálást tekintve ezek kedvező 
méretek, ugyanis mindegyik irányban osztható mindkét méret 16-tal. A felvételeket a $[0,1]$-es tartományra normalizáltuk.

A tanításhoz az adathalmazt a következőképpen generáltuk. A rendelkezésre álló felvételek 60\%-át a tréning-, 40\%-át pedig a teszthalmazhoz rendeltük hozzá. Ezután minden MR-felvételből, illetve az ahhoz tartozó, a manuális szegmentálásból származó maszkból 50-50db, $64 \times 64 \times 64$-es kockát vágtunk ki, véletlenszerü elhelyezkedéssel. A tréningteszt szétosztása a felvételek szintjén történt, tehát egy felvételből nem kerülhettek részek a tréning- és a teszthalmazba is.

Fontos kitérni a képekben fellelhető kiegyensúlyozatlanságra az osztályokat illetően. A tréninghalmazt tekintve megállapítható, hogy a maszkoknak átlagban csupán $3,18 \pm 2,87 \%$-a tartozik a térdporchoz, a medián érték pedig 2,78\%. Egy ilyen mértékú kiegyensúlyozatlanság esetén fennáll a veszélye annak, hogy a tanítás során a háló minden voxelt háttérként (azaz nem porcként) osztályoz, hiszen ebben az esetben a pontosság már 97\% körül lenne. Ebből két következtetés vonható le: egyrészt 'under-/oversampling' segítségével, másrészt az osztályok súlyozásával ki kell küszöbölni a kiegyensúlyozatlanságot, illetve a pontosság helyett más, a valóságot jobban leíró mutatók használata szükséges.

A $64 \times 64 \times 64$-es képek előállításakor ezért felvételenként a képek osztályeloszlását úgy határoztuk meg, hogy harmaduknál a térdporc aránya alacsony, harmaduknál közepes, harmaduknál magas legyen. Az alacsony, közepes, magas arányokat az adott felvételen található térdporcot tartalmazó 'bounding box' térdporcarányának a 0-33\%, 33-66\%, illetve 66-100\%-os 'percentile score' tartományokba esőként határoztuk meg.

\section{Az eredmények értékelése}

$\mathrm{Az}$ eredmények értékeléséhez a true positive rate (TPR) és a true negative rate (TNR), valamint a Dice similarity coefficient (DSC) mutatók használata mellett döntünk, melyek matematikai definíciói a következők:

$$
T P R=\frac{T P}{T P+F N} ; \quad T N R=\frac{T N}{T N+F P} ; \quad D S C=\frac{2 T P}{2 T P+F P+F N}
$$

A TP (true positive), TN (true negative) változók a térdporcként, illetve nem térdporcként jelölt és a háló által helyesen felismert voxelek számát, míg a $F N$ (false negative), FP (false positive) változók a háló által tévesen meghatározott voxelek számát jelölik.

Így a TPR (magyarul: szenzitivitás) azt mondja meg, hogy a valóban porcot ábrázoló voxelek hányad részét jelölte a hálózat is porcnak. Analóg módon, a TNR (magyarul: specificitás) a helyesen jelölt nem porc voxelek arányát adja meg az összes nem porc voxelből.

A DSC a szegmentációs feladatokban gyakran használt mutató, mely lényegében a tényleges és a javasolt szeg- mentációk közös részét (true positive) arányítja a tévesen felismert részekhez (false positive, false negative).

Mindhárom mutató (TPR, TNR, DSC) a $[0,1]$ intervallumban vesz fel értékeket, és ha a háló tökéletesen múködik, akkor mindhárom mutató értéke 1 .

\section{Hardver-és szoftverkörnyezet}

A MedInnoScan Kft. által a kutatás számára biztosított, Microsoft Azure virtuális szerver $4 \mathrm{db}$ Tesla K80-as 'graphics processing unit' egységet tartalmaz. Ezen a Google cég által fejlesztett, nyílt forráskódú Tensorflow könyvtár 2.2-es verzióját használva építettük fel hálózatunkat.

\section{Kisérletek}

A neuralis hálót először az eredeti verziójában futtattuk, ez képezte a 0 . kísérletet. Ezek után különböző módszereket alkalmaztunk az eredmények potenciális javítására. a) A háló generalizálóképességét elősegítendő [14] az a kísérlet tárgya egy olyan adataugmentáció volt, melyben a $64 \times 64 \times 64$-es képeken kismértékü $(-10 \% \ldots+10 \%)$, tengelyenként véletlenszerü nagyítást, illetve kicsinyítést alkalmaztunk (affin transzformáció). A TPR csekély javulását láthatjuk ennek következtében, azonban a TNR és a DSC ezzel szemben enyhén romlik, vagyis a fals pozitívok növekedésével jár a kísérlet.

b) A manuális szegmentálásnál bizonytalanság miatti kizárásra használt osztályt a képek, vagyis az egyes sample-ek súlyozásához használtuk fel. A b és a $c$ kísérlet azt célozza, hogy ezeken a területeken a hiba ne propagálódjon vissza, hiszen nem biztos, hogy a valóságban ténylegesen falsok. Ehhez a két kísérlet két különböző megközelítést használ: a súlyozás az egyiknél voxelenként, a másiknál pedig sample-enként történik. A $b$ kísérletnél, ha egy voxel a kizárt osztályhoz tartozik, akkor a tanítás során a hibákat összesítő hibafüggvénynek az ebből a voxelből származó részértéke 0 .

c) A c kísérletnél minden mintához egy szorzót rendelünk 0 és 1 között. Ez a szorzó akkor magas, ha a mintához arányaiban véve sok kizárt osztályhoz tartozó voxel van. Az ilyen voxelek száma a szorzó számításakor nemcsak az összes voxel számához, hanem a sample-ben található térdporchoz tartozó voxelek számához is aránylik. Mind a $b$, mind a $c$ kísérlet a TPR-mutató jelentős javulását jelzi, miközben a másik két mutató romlása kisebb mértékü, mint az a kísérlet esetében. A mintánkénti súlyozás (c) egy árnyalattal jobb eredményt hoz, mint a voxelenkénti súlyozás (b).

d) A d kísérlet tárgya egy alternatív hibafüggvény tesztelése. A fokális hibafüggvény lényege, hogy csak a legnagyobb hibákat propagálja vissza [15]. Ezáltal egyfajta rugalmasságot kölcsönöz a hálónak. E rugal- 
masság előnyös lehet a bizonytalan osztályozású területek szempontjából. A kísérlet azonban mind a $T P R$-, mind a DSC-mutató nagyon jelentős romlását hozza, így nem váltja be a hozzá füzött reményket.

e) A térdporcosztály kiegyensúlyozatlanságát kiküszöbölendő, a térdporchoz tartozó voxelek mintákban történő eloszlásán túl a hibafüggvény további manipulációja volt az e kísérlet célja. Az osztálysúlyozás azon alapul, hogy az alulreprezentált osztály hibáját, tehát esetünkben a valójában a térdporchoz tartozó voxelek hibáit egy szorzóval látjuk el [16]. A szorzó kiszámításának alapját a tréninghalmazban található osztályeloszlás képezte. A kísérlet nagyságrendi javulást mutat a TPR terén. Azonban - mint a többi kísérlet során, ennél a kísérletnél is - a TPR növekedése a fals pozitív arány növekedésével is jár, bár ez itt relatíve kisebb mértékü.

f) Mivel a térdporc a felvételeken nagyjából hasonló helyen található, és a térdporc orientációja minden felvételen megegyezik, logikusnak tünik segíteni a hálót azzal a pluszinformációval, hogy a $64 \times 64 \times 64$-es képben foglalt voxelekhez milyen koordináták tartoznak. Ezért az $f$ kísérletben az MR-felvételből kivágott, $64 \times 64 \times 64$-es képeket három további csatornával láttuk el, melyek az $x, y$ és $z$ koordinátákat tartalmazzák, normalizálva. A többi kísérlethez hasonlóan a TPR-mutató javul, a másik kettő azonban enyhén romlik.

g) Utolsó, g kísérletünkben három, a TPR-mutató legnagyobb javulását hozó, előző kísérletet vegyítettünk. Meglepő módon az eredmények elmaradnak az e kísérletben tapasztaltaktól. Mint az a többi kísérletben is megfigyelhető, a TPR-mutató javulása ez esetben is a TNR-és a DSC-mutató enyhe romlásával jár.

\section{Eredmények}

Az eredmények meghatározásához a hálózatot a teszthalmaz összes képén inferáltuk, és ezen szegmentációk pontosságát vizsgáltuk.

A kísérletek eredményeit az 1 . táblázat tartalmazza.

1. táblázat | A neuralis hálózat különböző módszerekkel történő tanítási kísérleteinek eredményei

\begin{tabular}{llccc}
\hline & Kísérlet & TPR & TNR & DSC \\
\hline o. & Eredeti verzió & 0,8022 & 0,9967 & 0,8056 \\
$a$ & Transzformáció & 0,8108 & 0,9961 & 0,7934 \\
$b$ & Voxelenkénti mintasúlyozás & 0,8337 & 0,9964 & 0,8049 \\
$c$ & Sample-enkénti mintasúlyozás & 0,8399 & 0,9966 & 0,8069 \\
$d$ & Fokális hibafüggvény & 0,5810 & $\mathbf{0 , 9 9 8 1}$ & 0,3279 \\
$e$ & Osztálysúlyozás & 0,9484 & 0,9884 & $\mathbf{0 , 8 1 3 2}$ \\
$f$ & Koordinátacsatorna & 0,8239 & 0,9958 & 0,7916 \\
$g$ & Vegyes $(b, d, f)$ & $\mathbf{0 , 9 5 3 2}$ & 0,9873 & 0,7967 \\
\hline
\end{tabular}

DSC = Dice hasonlósági együttható; TNR = specificitás; TPR = szenzitivitás
Megállapítható, hogy az e kísérlet hozta a legjobb eredményt a DSC tekintetében, és a TPR és a TNR is csak kissé marad el a legjobbtól. Tehát az e kísérletnek megfelelő hálózatot választottuk mint a legjobbat, és ennek eredményét tekintjük munkánk eredményének.

Az eddig tárgyalt eredmények a fentebb leírtak szerint elóállított teszthalmaz sample-jeire vonatkoztak. Célszerú azonban megvizsgálni az eredményeket a teszthalmazhoz sorolt egész MR-felvételekre vonatkoztatva is. A 4., 5. és 6. ábra a TPR-, a TNR-és a DSC-mutató eloszlását mutatja az egyes felvételekre vetítve, az e kísérlet szerint inferálva.

Átlagosan a teszthalmazhoz tartozó MR-felvételeken a mesterséges intelligencia a térdporc $89,54 \pm 5,19 \%$-át ismerte fel helyesen, ugyanez az érték a háttérhez tartozó voxelek esetében 99,80 \pm 0,05\%. A medián értékek $88,78 \%$, illetve $99,81 \%$. A 2. táblázat összefoglalja ezenkívül a legjobb és a legrosszabb eredményeket is.

Szintén érdekes megnézni egy adott MR-felvételen belül a mesterséges intelligencia által kiszámított valószínüségek eloszlását. A 7. ábra a teszthalmaz egy tetszőleges MR-felvételéhez tartozó inferálás eredményeit mutatja egy, a valószínúségeket bemutató logaritmikus hisztogram formájában.

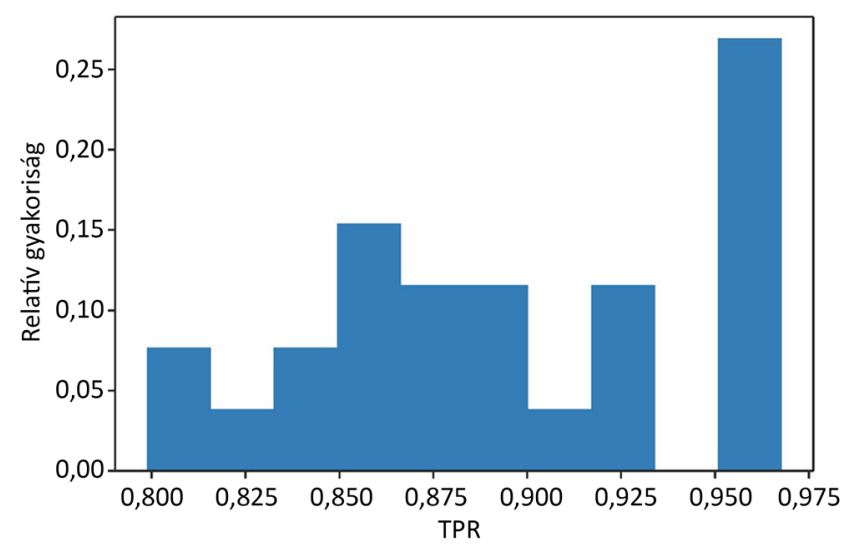

4. ábra $\quad$ A DSC (Dice hasonlósági együttható) eloszlása a teszthalmaz MR-felvételein

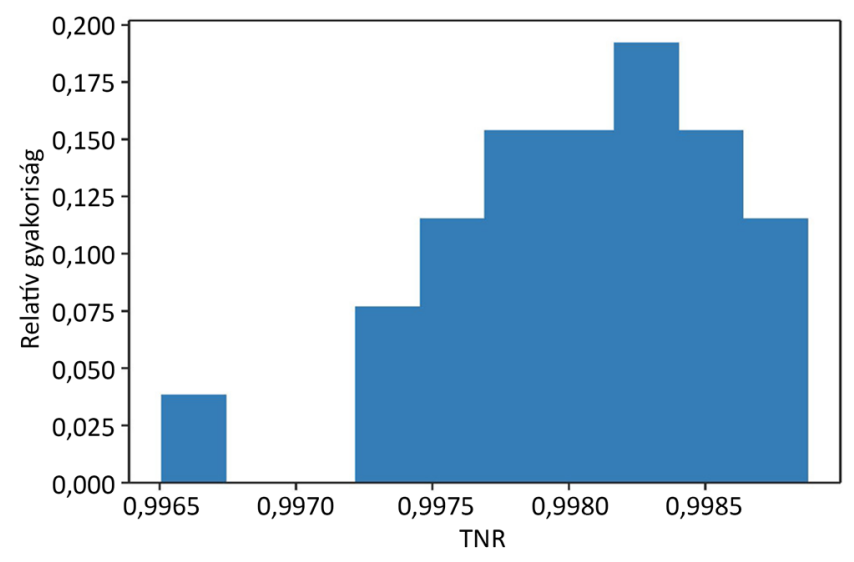

5. ábra $\mid$ A klasszifikáció valószínúségi értékeinek hisztogramja a teszthalmaz MR-felvételein 
A hálózat teszthalmazon kiértékelt eredményeinek különböző értékei a teszthalmaz elemei szerint

\begin{tabular}{lccc}
\hline & TPR & TNR & DSC \\
\hline Legrosszabb & 0,7988 & 0,9965 & 0,7326 \\
Átlag & 0,8954 & 0,9980 & 0,8161 \\
Medián & 0,8878 & 0,9981 & 0,8181 \\
Legjobb & 0,9677 & 0,9989 & 0,8669 \\
\hline
\end{tabular}

DSC = Dice hasonlósági együttható; TNR = specificitás; TPR = szenzitivitás

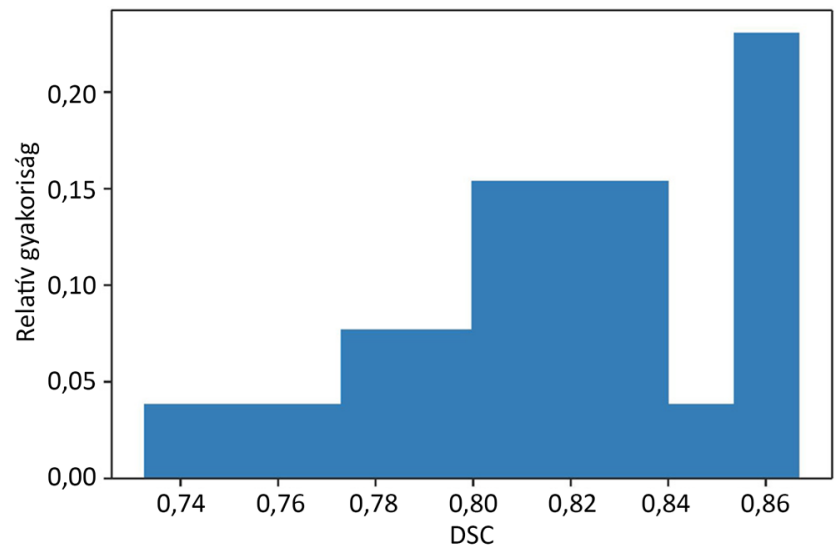

6. ábra $\mid$ Egy kézzel meghatározott femoralis térdporcgeometria

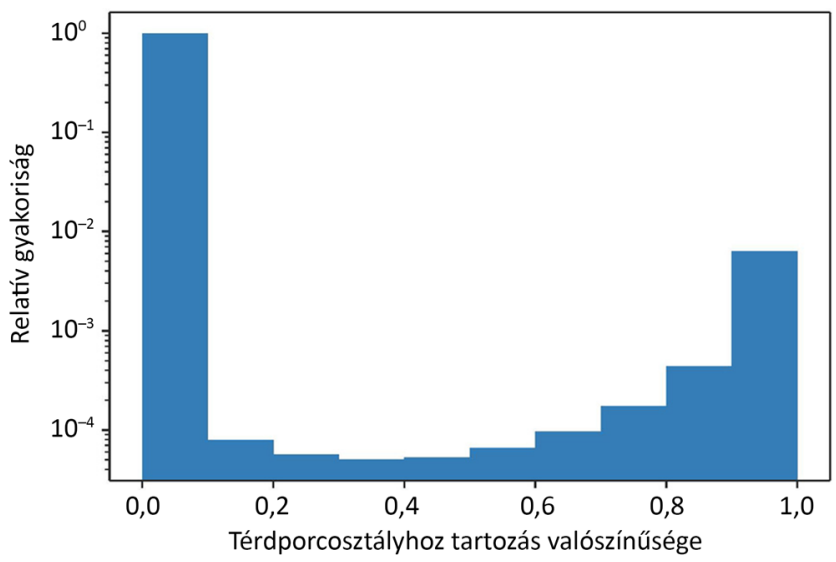

7. ábra

A mesterséges intelligencia által meghatározott femoralis térd porc-geometria (ugyanannak a porcnak a gépi feldolgozása, amely a 6. ábrán is látható)

Jól kivehető az egyértelmú bimodális eloszlás, mely arra bizonyíték, hogy a mesterséges intelligencia magabiztosan osztályozza a voxeleket.

Végül, az érthetőség kedvéért, a 8. és a 9. ábra bemutatja ugyanannak a femoralis térdporc-morfológiának a kézi, illetve a mesterséges intelligencia által meghatározott változatát.

$\mathrm{Az}$ eredmények mind optikailag, mind a számok fényében bizakodásra adnak okot. Ám további munkánkban a kísérletek során megfigyelt TPR-javulás és egyidejúleg a TNR-, valamint DSC-romlás, vagyis a fals
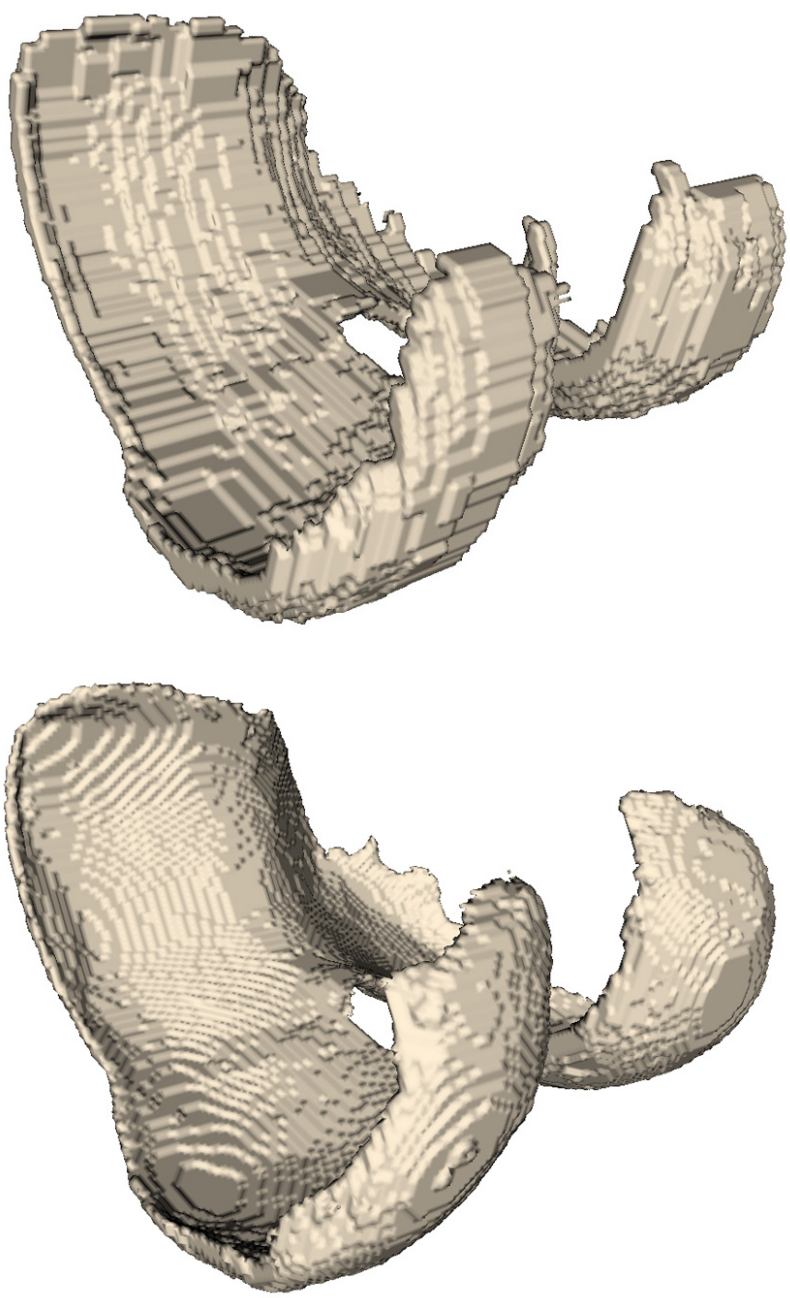

8. és 9. ábra Ugyanannak a femoralis térdporc-morfológiának a kézi, illetve a mesterséges intelligencia által meghatározott változata

pozitívok - tehát a mesterséges intelligencia által a térdporcosztályhoz rendelt, valójában azonban a háttérhez tartozó voxelek - számának növekedése megoldandó feladat. Egy következő lépésben a hibafüggvény további manipulációja szükséges ennek megakadályozására. Szintén szükséges az adathalmazok további növelése és a felvételeken a problémás területek pontos feltérképezése, lokalizációja.

\section{Megbeszélés}

A porchoz tartozó voxelek 90\%-os felismerése bizakodásra ad okot a mütéti tervezésben való gyakorlati hasznosíthatóság tekintetében. A tévesen kihagyott, 10\% voxel többsége olyan területen van, a porcszövet szélén, amely nem releváns az osteochondralis allograftok szempontjából. Egy másik jelentôs része a porc sérült, kopott területe mellett van, ahol a szakorvosoknak is nehéz megállapítaniuk, hogy egy-egy voxel még porcszövetet ábrázol, vagy már nem tekinthető annak. Mindezzel együtt, további munkánk során ezt a pontosságot kívánjuk növelni, részben a mesterséges intelligencia fejleszté- 
sével, részben további MR-felvételek bevonásával a tanításba.

Ezzel párhuzamosan dolgozunk a sérült területek felismerésén is. E két feladat végrehajtása után a donor porcáról, illetve a várakozó recipienseknek szükséges porcról matematikai modell készíthető, és az ideális párosítás optimalizációs algoritmusokkal megállapítható lesz.

Reményeink szerint munkánkkal hozzájárulhatunk majd a porckopás népegészségügyi szempontból is jelentős problémájának kezeléséhez.

Anyagi támogatás: A jelen kutatást a Magyar Kormány 2019. évi Tudományterületi Kiválósági Programja (TKP) finanszírozta, a Bioimaging kategóriában.

Szerzői munkamegosztás: H. L. és H. Gy. az ortopédiai szakmai részt írták, E. Zs. a radiológiait, Sz. P., S. J., Sz. E. pedig a mesterséges intelligenciával kapcsolatos részt. A cikk végleges változatát valamennyi szerző elolvasta és jóváhagyta.

Érdekeltségek: Sz. P. és S. J. a MedInnoScan Kft. tulajdonosa, illetve munkatársa, mely cég orvosi diagnosztikai célú mesterséges intelligenciák fejlesztésével foglalkozik. A többi szerzőnek nincsenek érdekeltségei.

\section{Irodalom}

[1] Riboh JC, Cvetanovich GL, Cole BJ, et al. Comparative efficacy of cartilage repair procedures in the knee: a network meta-analysis. Knee Surg Sports Traumatol Arthrosc. 2017; 25: 37863799.

[2] Beer AJ, Tauro TM, Redondo ML, et al. Use of allografts in orthopaedic surgery: Safety, procurement, storage, and outcomes. Orthop J Sports Med. 2019; 7: 2325967119891435.

[3] Chahal J, Gross AE, Gross C, et al. Outcomes of osteochondral allograft transplantation in the knee. Arthroscopy 2013; 29: 575-588.

[4] Hangody LR, Gál T, Szúcs A, et al. Osteochondral allograft transplantation from a living donor. Arthroscopy 2012; 28: $1180-1183$
[5] Gillies RJ, Kinahan PE, Hricak H. Radiomics: images are more than pictures, they are data. Radiology 2016; 278: 563-577.

[6] Renard Y, de Mestier L, Perez M, et al. Unraveling pancreatic segmentation. World J Surg. 2018; 42: 1147-1153.

[7] Weikert T, Akinci D'Antonoli T, Bremerich J, et al. Evaluation of an AI-powered lung nodule algorithm for detection and 3D segmentation of primary lung tumors. Contrast Media Mol Imaging 2019; 2019: 1545747.

[8] Rios Velazquez E, Aerts HJ, Gu Y, et al. A semiautomatic CTbased ensemble segmentation of lung tumors: comparison with oncologists' delineations and with the surgical specimen. Radiother Oncol. 2012; 105: 167-173.

[9] Eckstein F, Wirth W, Nevitt MC, et al. Recent advances in osteoarthritis imaging - the Osteoarthritis Initiative. Nat Rev Rheumat. 2012; 8: 622-630.

[10] Heimann T, Morrison BJ, Styner MA, et al. Segmentation of knee images: a grand challenge. In: Proceedings of MICCAI Workshop on Medical Image Analysis for the Clinic, Peking, 2010; pp. 207-214.

[11] Szegedy C, Liu W, Jia Y, et al. Going deeper with convolutions. In: Proceedings of the IEEE Conference on Computer Vision and Pattern Recognition, Boston, MA, 2015; pp. 1-9.

[12] Ronneberger O, Fischer P, Brox T. U-net: Convolutional networks for biomedical image segmentation. In: Navab $\mathrm{N}$, Hornegger J, Wells WM, et al. (eds.) Medical Image Computing and Computer-Assisted Intervention - MICCAI 2015. Part III. International Conference on Medical Image Computing and Computer-Assisted Intervention, Munich, 2015; pp. 234-241.

[13] Ioffe S, Szegedy C. Batch normalization: accelerating deep network training by reducing internal covariate shift. In: Proceedings of the 32nd International Conference on Machine Learning. PMLR 2015; 37: 448-456

[14] Dosovitskiy A, Springenberg JT, Riedmiller M, et al. Discriminative unsupervised feature learning with convolutional neural networks. In: Proceedings of the Advances in Neural Information Processing Systems Conference, Montréal, 2014; pp. 766-774.

[15] Lin TY, Goyal P, Girshick R, et al. Focal loss for dense object detection. In: Proceedings of the IEEE International Conference on Computer Vision, Venice, 2017; pp. 2999-3007.

[16] Xie S, Tu Z. "Holistically-nested edge detection". In: Proceedings of IEEE International Conference on Computer Vision, Santiago de Chile, 2015; pp. 1395-1403.

(Hangody László dr., e-mail: hangody.laszlo@hangody.hu)

A cikk a Creative Commons Attribution 4.0 International License (https://creativecommons.org/licenses/by/4.0/) feltételei szerint publikált Open Access közlemény, melynek szellemében a cikk bármilyen médiumban szabadon felhasználható, megosztható és újraközölhetö, feltéve, hogy az eredeti szerző és a közlés helye, illetve a CC License linkje és az esetlegesen végrehajtott módosítások feltüntetésre kerülnek. (SID_1) 